\title{
The Physicochemical and Immunological Characteristics of Rat Lymph Binding Protein for 25-Hydroxyvitamin $\mathrm{D}_{3}$
}

\author{
Toshio OKAnO, Sonoko MASUdA, Masako IsHIMINE, \\ Junko MURAI, Yukako YAMAMOTO, and Tadashi KOBAYASHI ${ }^{1}$ \\ Department of Hygienic Sciences, Kobe Women's College of \\ Pharmacy, Higashinada-ku, Kobe 658, Japan
}

(Received September 28, 1983)

\begin{abstract}
Summary The binding proteins for 25-hydroxyvitamin $\mathrm{D}_{3}\left(25-\mathrm{OH}-\mathrm{D}_{3}\right)$ in rat lymph and plasma were purified to apparent homogeneity as determined by sodium dodecyl sulfate disc gel electrophoresis. The purification procedures included the following techniques: gel filtration on Sephadex G-100 and G-200; affinity chromatography on Blue Sepharose CL-6B; ion-exchange chromatography on DEAE-Sepharose CL-6B; chromatofocussing on a Mono P column. Both proteins from lymph and plasma were eluted with the same retention time from an isoelectric column at a $\mathrm{pH}$ of approximately 4.53 and showed nearly identical data on the analysis of amino acid composition. When specific anti-lymph $25-\mathrm{OH}-\mathrm{D}_{3}$-binding protein antiserum was prepared in a rabbit, and Ouchterlony immunodiffusion was performed, the same precipitate line was observed on both lymph and plasma binding proteins. These results strongly suggest that a common transport protein exists in both rat lymph and plasma and circulates in the blood-lymph system.

Key Words lymph, plasma, 25-hydroxyvitamin $\mathrm{D}_{3}$, binding protein, electrophoresis, high-performance liquid chromatography, immunodiffusion, chromatofocussing, blood-lymph system
\end{abstract}

It is well known that in mammals, vitamin $\mathrm{D}_{3}$ is derived from the cutaneous photoconversion of 7-dehydrocholesterol under the influence of ultraviolet light in solar radiation (1-3), or from the intestinal absorption of natural foods of animal origin, and that the vitamin is first metabolized into 25 -hydroxyvitamin $\mathrm{D}_{3}(25-\mathrm{OH}$ $\mathrm{D}_{3}$ ) in the liver. The hepatic product is further metabolized into at least four more polar metabolites in the kidney, and among them, 1 $\alpha, 25$-dihydroxyvitamin $\mathrm{D}_{3}$ $\left(1 \alpha, 25-(\mathrm{OH})_{2}-\mathrm{D}_{3}\right)$ is the most potent in the initiation of active intestinal absorption

1 岡野登志夫, 増田園子, 伊志頜正子, 村井純子, 山本由佳子, 小林 正

Abbreviations: 25-OH- $\mathrm{D}_{3}, 25$-hydroxyvitamin $\mathrm{D}_{3} ; 1 \alpha, 25-(\mathrm{OH})_{2}-\mathrm{D}_{3}, 1 \alpha, 25$-dihydroxyvitamin $\mathrm{D}_{3} ; 24 R, 25-(\mathrm{OH})_{2}-\mathrm{D}_{3}, 24 R, 25$-dihydroxyvitamin $\mathrm{D}_{3}$; DBP, 25-hydroxyvitamin $\mathrm{D}_{3}$-binding protein; HPLC, high-performance liquid chromatography. 
of calcium and phosphorus, and in the mobilization of mineral from bone. The above vitamin $\mathrm{D}$ metabolites, including the parent vitamin, are mainly transported in blood, bound to a specific binding protein (DBP). This protein is an alpha globulin with a molecular weight of 52,000-58,000 $(4,5)$ containing one sterol binding site per molecule (6) and it shows maximal binding affinity with the following vitamin $\mathrm{D}_{3}$ metabolites: 25-hydroxy-26,23-lactone (25-OH- $\mathrm{D}_{3}$-26,23-lactone) (7), 25-OH- $\mathrm{D}_{3}$ and $24 R, 25$-dihydroxyvitamin $\mathrm{D}_{3}\left(24 R, 25-(\mathrm{OH})_{2}-\mathrm{D}_{3}\right)(8)$. Human plasma DBP is now recognized to be physico-chemically and immunologically identical with the group-specific component $(\mathrm{Gc})$ previously reported by Hirschfeld (9). This protein is synthesized in liver $(5,10)$ and it appears at high concentration $(6-8 \mu \mathrm{M})$ in plasma of human and rat (11-15). Although many researches on the physico-chemical and immunological properties of DBP have been reported, the biological significance of the protein in the transport of vitamin D and metabolites is still unclear. The apoDBP is present with an extreme excess of ligand and this fact suggests that the protein may have other functions besides the transport of vitamin D sterols. However, there is little information available on the turn-over rate in plasma or the metabolic fate of DBP. In order to clarify these aspects, we examined the bloodlymph circulatory system of DBP using experiments with rats cannulated via the thoracic duct.

In this paper, we describe our findings that lymph DBP is physico-chemically and immunologically identical with the plasma.

\section{EXPERIMENTAL}

Chemicals. Commercial grade (Philips-Duphar Co., The Netherlands) 25-OH$\mathrm{D}_{3}$ was used as a standard. Organic solvents were purified by the usual methods and distilled before use. Sephadex products, DEAE-Sepharose CL-6B and Blue Sepharose CL-6B were purchased from Pharmacia Fine Chemicals (Sweden). Other chemicals of analytical grade were used.

Animals. Male Wistar-strain rats weighing about $250 \mathrm{~g}$ were used.

Collection of lymph and plasma. After peroral administration of cottonseed oil to rats, the thoracic duct was cannulated with polyethylene tubing (size 2, Imamura Co., Ltd.) under light ether anesthesia according to the method of Bollman et al. (16). The lymph was collected in a small flask containing a small amount of sodium azide as an antimicrobial. A cannula was brought out through the abdominal wound and the rat was placed in a restraining cage during the collection of lymph. During collection of lymph, rats were fed a commercial chow (Nosanko Co., Osaka) and water containing $0.9 \% \mathrm{NaCl}$ ad libitum. The collection of plasma was performed by heart puncture.

Elimination of chylomicrons from lymph. The lymph obtained above was mixed with the same volume of chilled $0.9 \% \mathrm{NaCl}$ solution in a Polytron homogenizer, and the mixture was centrifuged at $7.8 \times 10^{4} \mathrm{~g}$ for $60 \mathrm{~min}$ at $4^{\circ} \mathrm{C}$ to separate chylomicrons. The supernatant chylomicrons were carefully removed with a syringe and the 
resulting transparent lower liquid layer was designated as chylomicron-free lymph. Seventy-five $\mathrm{ml}$ of lymph thus obtained was dialyzed against deionized water at $4^{\circ} \mathrm{C}$ for $24 \mathrm{~h}$ and then lyophilized. The lyophilized lymph was resolubilized in $40 \mathrm{ml}$ of $1 / 15 \mathrm{M}$ phosphate buffer ( $\mathrm{pH} 7.4$ ) containing $0.15 \mathrm{M} \mathrm{NaCl}$ and $0.03 \%$ sodium azide.

Incubation of chylomicron-free lymph and plasma with $25-\mathrm{OH}-\mathrm{D}_{3}$. The lymph solution obtained above and plasma $(40 \mathrm{ml})$ were incubated with $80 \mu \mathrm{g}$ of $25-\mathrm{OH}-\mathrm{D}_{3}$ dissolved in $1 \mathrm{ml}$ of ethanol for $24 \mathrm{~h}$ at $4^{\circ} \mathrm{C}$ and directly subjected to the following isolation and purification steps.

Purification of rat-lymph DBP and plasma DBP. The rat-lymph DBP and plasma DBP were respectively purified from thoracic duct lymph $(450 \mathrm{ml}$; from 6 rats) and plasma ( $200 \mathrm{ml}$; from 40 rats) by the procedure shown in Chart 1 . All columns for gel filtration were equilibrated and eluted with $1 / 15 \mathrm{M}$ phosphate buffer (pH 7.4) containing $0.15 \mathrm{M} \mathrm{NaCl}$ and $0.03 \%$ sodium azide. For ion-exchange column chromatography, DEAE-Sepharose CL-6B was equilibrated with $0.05 \mathrm{M}$ Tris $\cdot \mathrm{HCl}$ buffer $(\mathrm{pH} 7.0)$ and eluted with a linear gradient of $0.05-0.3 \mathrm{M} \mathrm{NaCl}$ in $0.05 \mathrm{~m}$ Tris $\cdot \mathrm{HCl}$ buffer $(\mathrm{pH} 7.0)$. For affinity chromatography, Blue Sepharose CL$6 \mathrm{~B}$ was equilibrated and eluted with $0.05 \mathrm{M}$ Tris $\cdot \mathrm{HCl}$ buffer $(\mathrm{pH} 7.0)$ containing $0.1 \mathrm{M} \mathrm{KCl}$. During the purification, both lymph DBP and plasma DBP were monitored by measuring the quantity of bound $25-\mathrm{OH}-\mathrm{D}_{3}$ using the HPLC method and by absorbance (protein) at $280 \mathrm{~nm}$ with a UV monitor (Gilson Co., U.S.A).

Chromatofocussing of lymph DBP and plasma DBP. Chromatofocussing of lymph DBP and plasma DBP was performed under the following conditions. A Mono P HR 5/20 column (Pharmacia, Sweden) was equilibrated with $0.025 \mathrm{M} N$ methylpiperazine $\cdot \mathrm{HCl}$ buffer $(\mathrm{pH}$ 6.3). Each approximate $100 \mu \mathrm{g}$ of partially purified lymph DBP and plasma DBP obtained from the Blue Sepharose CL-6B column chromatography was dissolved in $500 \mu$ l of the buffer mentioned above and then applied to the column. Elution was carried out with $40 \mathrm{ml}$ of Polybuffer 74 (Pharmacia) with a linear $\mathrm{pH}$ gradient from $\mathrm{pH} 5$ to 4 at a constant flow rate of $1 \mathrm{ml} / \mathrm{min}$.

Assay of $25-\mathrm{OH}-\mathrm{D}_{3}$ by $\mathrm{HPLC}$. Assay of $25-\mathrm{OH}-\mathrm{D}_{3}$ in the eluates obtained from various column chromatography runs was carried out according to our methods reported previously (17). Exactly $0.5 \mathrm{ml}$ of each eluate was placed in a test tube with a stopper. Three $\mathrm{ml}$ of methanol and $1.5 \mathrm{ml}$ of methylene dichloride were added and mixed using a Vortex mixer for $2 \mathrm{~min}$. After standing for $1 \mathrm{~h}$, the mixed solution was centrifuged at 3,000 rpm for $5 \mathrm{~min}$. Then, $1 \mathrm{ml}$ of methylene dichloride and $1 \mathrm{ml}$ of water were added. The mixed solution was separated into two layers and the lower layer was drawn off into a different tube. The upper layer was extracted further with $2 \mathrm{ml}$ of methylene dichloride and the extracted layers were combined. The solvent was evaporated off under reduced pressure, and the residue was dissolved in $250 \mu \mathrm{l}$ of $5.5 \%$ isopropanol in $n$-hexane. Then, $50 \mu$ l of the solution was injected into a Shimadzu LC-3A high-performance liquid chromatograph equipped with an autosampler (WISP model 710A, Waters Associates, Inc., U.S.A). Separation of 25$\mathrm{OH}-\mathrm{D}_{3}$ was carried out in a stainless-steel tube $(250 \times 4.6 \mathrm{~mm}$ i.d. $)$ packed with 
Zorbax SIL( straight-phase type, Dupont Co., U.S.A) using 5.5\% isopropanol in $n$ hexane as a mobile phase. The flow rate was $1.0 \mathrm{ml} / \mathrm{min}$ (column pressure; $40 \mathrm{~kg} / \mathrm{cm}^{2}$ ). Under these conditions, the retention time of $25-\mathrm{OH}-\mathrm{D}_{3}$ was $13.4 \mathrm{~min}$ and $25-\mathrm{OH}-\mathrm{D}_{3}$ could be easily determined by reading the peak height on the chromatogram.

Preparation of an antiserum to lymph $D B P$. One milligram of pure lymph DBP in $1 / 15 \mathrm{M}$ phosphate buffer, $\mathrm{pH} 7.4$, was emulsified with an equal volume of complete Freund's adjuvant and injected into multiple subcutaneous sites of a 3 to 4-month-old rabbit. After 4 weeks, a booster injection with $0.5 \mathrm{mg}$ of the DBP emulsified with complete Freund's adjuvant was made into the lymph node of footpads. Ten days after the booster injection, the animal was sacrificed by bleeding from the carotid artery.

Immunodiffusion. Immunodiffusion in gel was carried out by the method of Ouchterlony (18) using gel prepared from $1 \%$ agarose in Tris barbiturate buffer $(\mathrm{pH}$ 8.6 , ion intensity $=0.02$ ). Ten $\mu \mathrm{l}$ of a sample solution was applied per well and good results were obtained. After immunoreaction for $24 \mathrm{~h}$, the gel was examined under illumination with dim light. For staining, the gel was washed for 1 day with $0.9 \%$ $\mathrm{NaCl}$ and subsequently with distilled water before drying in air. The gel was stained with $0.2 \%$ (wt $/ \mathrm{vol}$ ) Coomassie Brilliant Blue in $5 \%$ ethanol (vol $/ \mathrm{vol}$ ) for $20 \mathrm{~min}$, destained with $5 \%$ ethanol in $7.5 \%$ acetic acid (vol/vol) for $1 \mathrm{~h}$ and then dried in air.

Determination of protein. Protein was determined by the method of Lowry et al. (19) using human serum albumin as a standard.

Sodium dodecyl sulfate (SDS)-disc gel electrophoresis of lymph DBP and plasma $D B P$. SDS-disc gel electrophoresis was carried out by the method of Weber and Osborn (20) using a separating gel containing 5\% acrylamide with $0.1 \%$ SDS.

Amino acid analysis. Bacause small amounts of pure DBP were available, amino acid analysis was carried out once only. A sample of $0.5-1.0 \mathrm{mg}$ of lymph DBP or plasma DBP was hydrolyzed in $6 \mathrm{~N} \mathrm{HCl}$ in an evacuated sealed tube at $110^{\circ} \mathrm{C}$ for $24 \mathrm{~h}$. Amino acid analysis was performed using a Hitachi model 835 amino acid auto-analyzer (Hitachi, Ltd., Japan).

HPLC analysis of lymph DBP and plasma DBP. HPLC analysis of lymph DBP and plasma DBP using an ion-exchange column ( a Mono Q column, Pharmacia) was carried out under the following conditions. A mono Q column was equilibrated with $20 \mathrm{~mm}$ bis · Tris · propane buffer ( $\mathrm{pH} 7.0$ ). About $100 \mu \mathrm{g}$ respectively of lymph DBP and plasma DBP was dissolved in $250 \mu$ l of the same buffer solution and then applied to the column. Elution was carried out with the same buffer in the form of a linear gradient of $0-0.5 \mathrm{M} \mathrm{KCl}$ at a constant flow rate of $1.0 \mathrm{ml} / \mathrm{min}$.

\section{RESULTS}

\section{Purification of lymph $D B P$ and plasma $D B P$}

The steps of purification of lymph DBP and plasma DBP performed in this study are presented in Chart 1. On chromatofocussing used as a final purification 


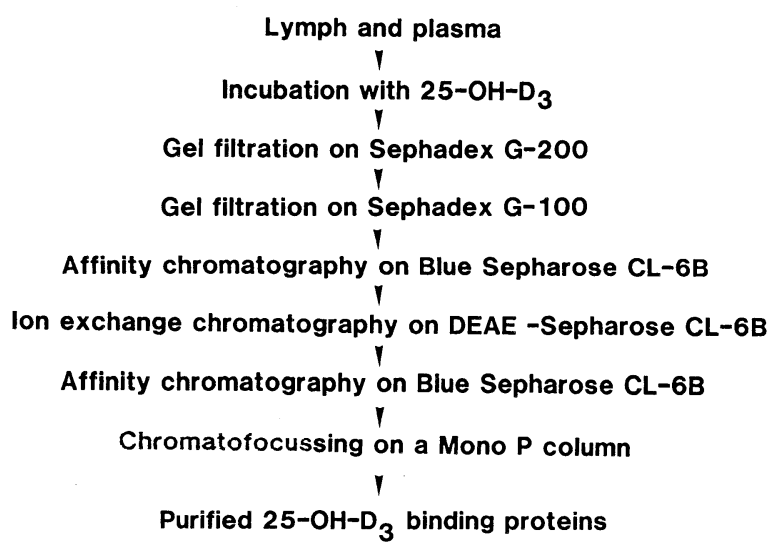

Chart 1. Steps for purification of $25-\mathrm{OH}-\mathrm{D}_{3}$ binding proteins (DBP) from rat lymph and plasma.

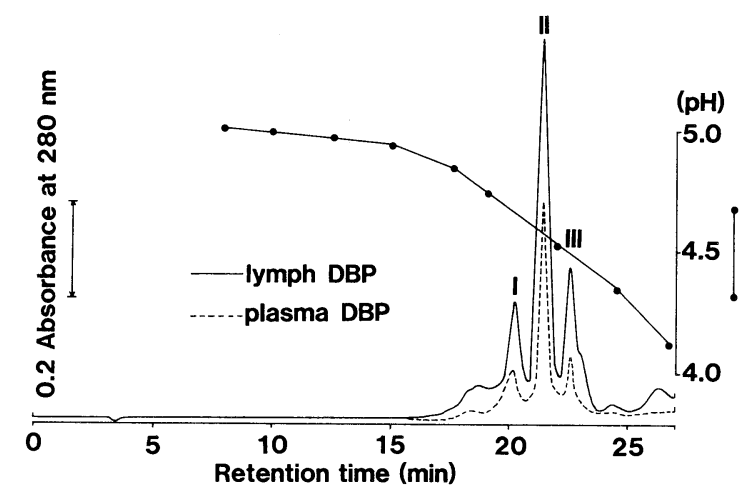

Fig. 1. Profiles on chromatofocussing of lymph DBP and plasma DBP.

step, both proteins were similarly separated into one major and two minor peaks, denoted as lymph DBP I, II, III and plasma DBP I, II, III, respectively, according to the order of elution from an isoelectricfocussing column (Fig. 1). The lymph DBP II and III and plasma DBP II and III were bound to $25-\mathrm{OH}-\mathrm{D}_{3}$. The lymph DBP II and plasma DBP II showed a higher binding affinity to $25-\mathrm{OH}-\mathrm{D}_{3}$ than the lymph DBP III and plasma DBP III. Therefore, we thought that the lymph DBP II and plasma DBP II were major $25-\mathrm{OH}-\mathrm{D}_{3}$-binding proteins and these proteins were subjected to the following physico-chemical and immunological analyses.

\section{HPLC analyses of lymph DBP II and plasma DBP II}

As shown in Fig. 2, the lymph DBP II and plasma DBP II were eluted similarly from an anion-exchange column at the concentration of $0.35 \mathrm{M} \mathrm{KCl}$ in the form of a linear gradient of $0-0.5 \mathrm{M} \mathrm{KCl}$ in $20 \mathrm{~mm}$ bis $\cdot$ Tris $\cdot$ propane. 


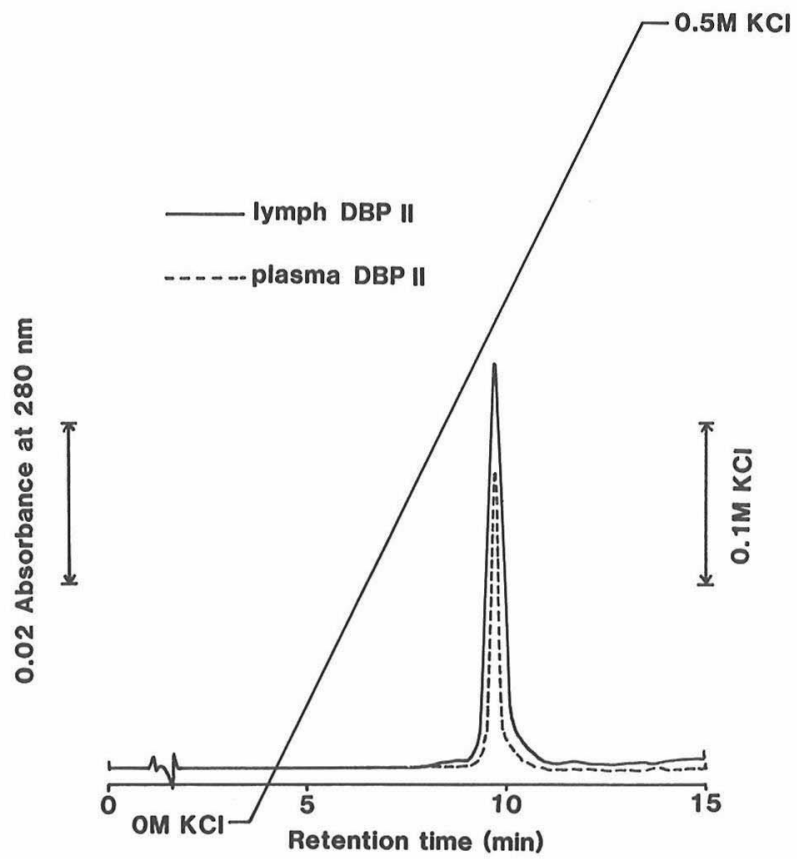

Fig. 2. HPLC profiles of lymph DBP II and plasma DBP II on an ion-exchange column.
(A)
(B)
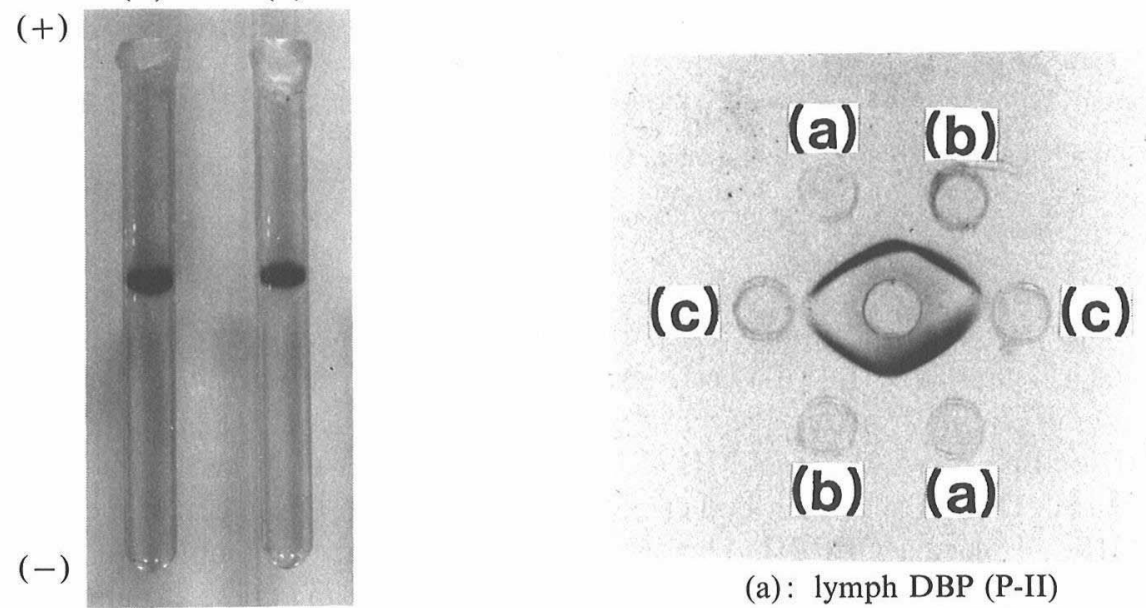

(A): lymph DBP II

(a): lymph DBP (P-II)

(B): plasma DBP II

Fig. 3

(b) : plasma DBP (P-II)

(c): phosphate buffer Fig. 4

Fig. 3. Sodium dodecyl sulfate-disc gel electrophoreses of lymph DBP II and plasma DBP II.

Fig. 4. Ouchterlony immunodiffusion of lymph DBP II and plasma DBP II against anti-lymph DBP II antiserum. 
Table 1. Amino acid analyses of lymph DBP II and plasma DBP II.

\begin{tabular}{lccccc}
\hline & \multicolumn{2}{c}{ Amino acid residues $/ 1,000$} & & $\begin{array}{c}\text { Estimated number of residues } \\
\text { per DBP molecule }\end{array}$ \\
\cline { 2 - 3 } \cline { 5 - 6 } Amino acid & Lymph DBP II & Plasma DBP II & & Lymph DBP II & Plasma DBP II \\
\cline { 2 - 3 } Aspartic acid & 65.54 & 65.22 & & 26 & 26 \\
Threonine & 76.94 & 75.28 & & 30 & 30 \\
Serine & 106.83 & 105.46 & & 42 & 41 \\
Glutamic acid & 157.80 & 156.97 & & 62 & 61 \\
Proline & 59.31 & 59.28 & & 23 & 23 \\
Glycine & 34.11 & 33.52 & & 13 & 13 \\
Alanine & 67.36 & 65.68 & & 26 & 26 \\
Valine & 32.56 & 32.45 & & 13 & 13 \\
1/2 Cystine & 26.64 & 27.88 & & 10 & 11 \\
Methionine & 30.28 & 31.40 & & 12 & 12 \\
Isoleucine & 20.41 & 21.49 & & 8 & 9 \\
Leucine & 104.91 & 105.46 & & 41 & 42 \\
Tyrosine & 39.09 & 41.91 & & 15 & 16 \\
Histidine & 9.77 & 10.38 & & 4 & 4 \\
Phenylalanine & 42.35 & 41.60 & & 17 & 16 \\
Lysine & 81.35 & 81.07 & & 32 & 31 \\
Arginine & 45.51 & 44.95 & & 18 & 18 \\
Total & $1,000.00$ & $1,000.00$ & & 392 & 392 \\
\hline
\end{tabular}

3. SDS-disc gel electrophoresis of lymph DBP II and plasma DBP II

Both proteins showed an apparently identical homogenous band of protein (Fig. 3).

\section{Amino acid analysis of lymph DBP II and plasma DBP II}

The results of amino acid analysis on the lymph DBP II and plasma DBP II are shown in Table 1. The amino acid compositions of the two proteins are extremely close to one another, and furthermore, the values obtained are in good agreement with the respective data on plasma DBP previously reported by Bouillon et al. (21).

5. Immunodiffusion of lymph DBP II and plasma DBP II against anti-lymph DBP II antiserum

When the antiserum to lymph DBP II was allowed to diffuse in gel against lymph DBP II and plasma DBP II, the same single line of immunoprecipitation was observed (Fig. 4).

\section{DISCUSSION}

In the present study, we have demonstrated that the physico-chemical and Vol. 30, No. 2, 1984 
immunological properties of DBP purified from rat thoracic lymph are almost identical with those of DBP from rat plasma. These findings strongly suggest the possibility that DBP having a specific binding for vitamin $\mathrm{D}$ and all of the metabolites is circulating in the blood-lymph stream system. It can easily be anticipated that the plasma DBP also exists in lymph because the intravascular lymph mainly consists of the components of blood filtered from peripheral blood vessels. However, few reports have directly confirmed these aspects and the relationships between vascular and therefore lymphatic turn-over rate or metabolic fate of DBP are also still unknown. Our present study demonstrates that the same $25-\mathrm{OH}-\mathrm{D}_{3}$ binding protein exists in both rat plasma and lymph, but it has not yet been clarified that the proteins are derived from the same organ. It is well known that DBP is synthesized in the liver (5), but we have not yet confirmed that lymph DBP is also synthesized in the same organ. The fact that lymph DBP and plasma DBP are the same protein induces another important merit for the investigations. Skill in performing the lymph cannulation of rats is generally required, and if the technique is skilfully carried out, much more lymph can be obtained (It is possible to collect $500-1,000 \mathrm{ml}$ of lymph from a rat for a week). Therefore, lymph is an important source of large amounts of pure DBP.

On the other hand, the technique to purify DBP from rat plasma is rather difficult, because the DBP has properties which include polymerization with the protein itself and interaction with actin, a protein commonly distributed in tissues and blood (22). Since lymph containing extremely small amounts of actin does not have such demerits as observed in plasma, a more effective an simpler procedure to purify DBP is possible by use of lymph. As with many other sterol-binding proteins, rat plasma $\mathrm{DBP}$ has a single binding site for its ligand and consists of a single polypeptide chain. On chromatofocussing used as a final step for purification of DBP in our experiment, both lymph DBP and plasma DBP were similarly separated into one major and two minor protein peak(s). Among them, the lymph DBP II, III and plasma DBP II, III were the peaks having the capability to bind $25-\mathrm{OH}-\mathrm{D}_{3}$. The lymph DBP II and plasma DBP II contained about 4 times as much $25-\mathrm{OH}-\mathrm{D}_{3}$ as the lymph DBP III and plasma DBP III. Therefore, we are now investigating whether these peaks are identical to one another. Furthermore, the detailed characteristics and significances of the lymph DBP III and plasma DBP III are also being investigated and the results will be reported in the future.

The authors wish to thank Dr. J. Tsutsumi and Mr. Y. Tomono, Section of Biopharmacy and Pharmakokinetics, Eisai Co., Ltd., for their valuable advice on the procedure for collection of thoracic duct lymph. We are indebted to Mr. J. Okura, Fine Chemicals Division, Pharmacia (Japan) Co., Ltd., for his help in the chromatofocussing. We also thank Mr. J. Tanabe, Department of Biochemistry of our college for the amino acid analysis of $\mathrm{DBP}$. 


\section{REFERENCES}

1) Okano, T., Yasumura, M., Mizuno, K., and Kobayashi, T. (1978): In vivo and in vitro conversion of 7-dehydrocholesterol into vitamin $\mathrm{D}_{3}$ in rat skin by ultraviolet ray's irradiation. J. Nutr. Sci. Vitaminol., 24, 47-56.

2) Okano, T., Mizuno, K., and Kobayashi, T. (1978): Identification and determination of 25-hydroxyvitamin $\mathrm{D}_{3}$ in the blood and liver of vitamin D-deficient rats irradiated with ultraviolet light. J. Nutr. Sci. Vitaminol., 24, 511-518.

3) Okano, T., Mizuno, K., Matsuyama, N., Nobuhara, N., and Kobayashi, T. (1979): Gas-liquid chromatography/mass spectrometric identification of previtamin $\mathrm{D}_{3}$ and vitamin $\mathrm{D}_{3}$ in the skin of vitamin $\mathrm{D}$-deficient rats irradiated with ultraviolet light. Recl. Trav. Chim. Pays-Bas, 98, 253-257.

4) Imawari, M., and Goodman, D. S. (1977): Immunological and immunoassay studies of the binding protein for vitamin $\mathrm{D}$ and its metabolites in human serum. J. Clin. Endocrinol. Metab., 59, 432-442.

5) Bouillon, R., Van Baelen, H., and De Moor, P. (1977): The measurement of the vitamin D-binding protein in human serum. J. Clin. Endocrinol. Metab., 45, 225-231.

6) Imawari, M., Kida, K., and Goodman, D. S. (1976): The transport of vitamin D and its 25-hydroxy metabolite in human plasma. J. Clin. Invest., 58, 514-523.

7) Horst, R. L., Pramanik, B. C., Reinhardt, T. A., Shiuey, S. J., Partridge, J. J., Uskokovic, M. R., and Napoli, L. L. (1982): Binding properties of 23S,25-dihydroxyvitamin $\mathrm{D}_{3}$ : an in vivo metabolite of vitamin $\mathrm{D}_{3}$. Biochem. Biophys. Res. Commun., 106, 1006-1011.

8) Haddad, J. G., Min, C., Mendelsohn, M., Slatopolsky, E., and Harn, T. J. (1977): Competitive protein-binding radioassay of 24,25-dihydroxy-vitamin D in sera from normal and anephric subjects. Arch. Biochem. Biophys., 182, 390-395.

9) Hirschfeld, J. (1959): Immunoelectrophoretic demonstration of quantitative differences in human sera and their relation to the hepatoglobins. Acta Pathol. Microbiol. Scand., 47, 160-168.

10) Prunier, J. H., Bearn, A. G., and Cleve, H. (1964): Site of formation of the group specific component and certain other serum proteins. Proc. Soc. Exp. Biol. Med., 115, 1005-1007.

11) Haddad, J. G., and Walgate, J. (1976): 25-Hydroxyvitamin D transport in human plasma. Isolation and partial characterization of calcifidiol binding protein. J. Biol. Chem., 251, 4803-4809.

12) Bouillon, R., Van Baelen, H., Rombauts, W., and De Moor, P. (1976): The purification and characterization of the human serum binding protein for the 25-hydroxycholecalciferol. Identity with group-specific component. Eur. J. Biochem., 66, 285-291.

13) Bouillon, R., Van Assche, F. A., Van Baelen, H., Heyns, W., and De Moor, P. (1981): Influence of the vitamin D-binding protein on the serum concentration of 1,25dihydroxyvitamin $\mathrm{D}_{3}$ concentration. J. Clin. Invest., 67, 589-596.

14) Hillman, L. S., and Haddad, J. G. (1983): Serial analyses of serum vitamin D-binding protein in preterm infants from birth to postconceptual maturity. J. Clin. Endocrinol. Metab., 56, 189-191.

15) Bouillon, R., Van Doren, G., Van Baelen, H., and De Moor, P. (1978): Immunochemical measurement of the vitamin D-binding protein in rat serum. Endocrinology, 102, $1710-1715$.

16) Bollman, L. J., Cain, C., and Grindlay, J. H. (1948): Techniques for the collection of 
lymph from the liver, small intestine or thoracic duct of the rat. J. Lab. Clin. Med., 33, $1349-1352$.

17) Okano, T., Mizuno, N., Shida, S., Takahashi, N., Kobayashi, T., Nakao, H., Kuroda, E., Kodama, S., and Matsuo, T. (1981): A method for simultaneous determination of 25-hydroxyvitamin $\mathrm{D}_{2}$ and 25-hydroxyvitamin $\mathrm{D}_{3}$ in human plasma by using two steps of high-performance liquid chromatography. J. Nutr. Sci. Vitaminol., 27, 43-54.

18) Ouchterlony, O. (1962): Diffusion in gel methods for immunological analysis. II. Prog. Allergy, 6, 30-154.

19) Lowry, O. H., Rosebrough, N. J., Farr, A. L., and Randall, R. J. (1951): Protein measurement with Folin phenol reagent. J. Biol. Chem., 193, 265-275.

20) Weber, K., and Osborn, M. (1969): The reliability of molecular weight determinations by dodecyl sulfate-polyacrylamide gels electrophoresis. J. Biol. Chem., 244, 4406-4412.

21) Bouillon, R., Van Baelen, H., Rombauts, W., and De Moor, P. (1977): The isolation and characterization of the vitamin D-binding protein from rat serum. J. Biol. Chem., 253, 4426-4431.

22) Shinomiya, K., Shinomiya, T., Yoshida, K., and Kimura, H. (1982): Conversion of plasma group-specific component (vitamin $\mathrm{D}$ binding protein) to a macromolecule by a protein factor in tissue extracts. J. Biochem., 92, 1163-1171. 